\title{
Interleukin 1 Inhibits Insulin Secretion from Isolated Rat Pancreatic Islets by a Process That Requires Gene Transcription and mRNA Translation
}

\author{
Jonathan H. Hughes, * Jerry R. Colca, ${ }^{5}$ Richard A. Easom, ${ }^{\star}$ John Turk, ${ }^{\ddagger}$ and Michael L. McDaniel* \\ ${ }^{*}$ Department of Pathology, ${ }^{\ddagger}$ Division of Laboratory Medicine and Department of Internal Medicine, Washington University \\ School of Medicine, Saint Louis, Missouri 63110; and ${ }^{\S}$ The Upjohn Company, Kalamazoo, Michigan 49001
}

\begin{abstract}
Recombinant human IL $1 \beta$ inhibits glucose-induced insulin secretion from isolated pancreatic islets and from purified $\beta$-cells obtained by fluorescence-activated cell sorting (FACS) of dispersed islet cells. Brief (1 h) exposure of isolated islets to IL 1 produces sustained inhibition of insulin secretion for at least 17 $h$ after the IL 1 has been removed from the culture medium. An inhibitory effect of IL 1 on insulin secretion is not observed when islets are coincubated with an inhibitor of DNA transcription (actinomycin D). This finding indicates that the inhibitory effect of IL 1 on insulin secretion requires transcription of one or more genes during the first hour of exposure of islets to IL 1. The inhibitory effect of IL 1 on insulin secretion also requires mRNA translation, because three structurally distinct inhibitors of protein synthesis (cycloheximide, anisomycin, and puromycin) prevent IL 1-induced inhibition of insulin secretion when added to islets after the 1-h exposure to IL 1. Two-dimensional gel electrophoresis of islet proteins metabolically labeled with ${ }^{35}$ S]methionine demonstrates that IL 1 augments the expression of a 65-kD (pl 6.5) protein by $>$ 2.5-fold. These findings indicate that biochemical events occurring within $1 \mathrm{~h}$ of exposure of islets to IL 1 lead to an inhibition of insulin secretion that persists for at least $17 \mathrm{~h}$ after the removal of IL 1 . One of the early biochemical effects of IL 1 on islets is gene transcription ( $0-1$ h), which is followed by mRNA translation (after $1 \mathrm{~h}$ ). Our results suggest that the inhibitory effect of IL 1 on insulin secretion is mediated by protein(s) whose synthesis is induced by IL 1. (J. Clin. Invest. 1990. 86:856-863.) Key words: cytokine - pancreatic $\beta$-cell • diabetes mellitus • protein synthesis • two-dimensional gel electrophoresis
\end{abstract}

\section{Introduction}

IL 1 is a $17.5-\mathrm{kD}$ polypeptide produced by macrophages and other cells. IL 1 is recognized as an important mediator of inflammation and immunity and exerts effects on a number of cellular targets. Biological effects of IL 1 include activation of and induction of proliferation by $T$ lymphocytes (1), induction of fever by direct action on the hypothalamus (2), and stimula-

Address reprint requests to Dr. McDaniel, Department of Pathology, Box 8118, Washington University School of Medicine, 660 South Euclid Avenue, St. Louis, MO 63110.

Received for publication 18 September 1989 and in revised form 1 May 1990.

J. Clin. Invest.

(c) The American Society for Clinical Investigation, Inc.

$0021-9738 / 90 / 09 / 0856 / 08 \$ 2.00$

Volume 86, September 1990, 856-863 tion of acute-phase protein synthesis by hepatocytes (3). A recently recognized effect of IL 1 is inhibition of insulin secretion by isolated pancreatic islets (4-11). This finding has engendered interest in the possibility that IL 1 may participate in the pathogenesis of insulin-dependent diabetes mellitus or in the physiologic modulation of insulin secretion (reviewed in references 12 and 13 ).

Little is known about the biochemical mechanism(s) whereby IL 1 inhibits insulin secretion. Study of the inhibitory influence of IL 1 on insulin secretion is complicated by the fact that IL 1 exerts this effect quite slowly. Previous studies of the inhibitory effect of IL 1 on insulin secretion have involved continuous exposure of islets to IL 1 for several hours or days. While these studies have yielded a substantial body of information about the biochemical effects of IL 1 on islets, they have not revealed any close link between these biochemical effects and the inhibition of insulin secretion by IL 1. For example, long periods of exposure of islets to IL 1 have been shown to inhibit glucose oxidation (8), glucose-induced $\mathrm{Ca}^{2+}$ uptake (14), and inositol phosphate production (17). and to stimulate $\mathrm{PGE}_{2}$ biosynthesis $(15,16)$. What relationship these events bear to the inhibition of insulin secretion by IL 1 , however, remains obscure.

The purposes of this study were to examine biochemical changes induced by IL 1 during the first hour of exposure to islets and to relate these effects to the inhibition of insulin secretion, which develops several hours later. We have found that very short periods of exposure of islets to IL 1 are sufficient to produce all of the biochemical changes necessary to inhibit glucose-induced insulin secretion at later time points. These studies involved exposure of islets to IL 1 for $1 \mathrm{~h}$, followed by serial measurements of glucose-induced insulin secretion at various times up to $17 \mathrm{~h}$ after the removal of the IL 1 from the culture medium. This experimental model has also been used to examine the participation of gene transcription and mRNA translation in the inhibition of insulin secretion by IL 1.

\section{Methods}

Male Sprague-Dawley rats (200-300 g) were purchased from Sasco Inc. (O'Fallon, MO). Collagenase was obtained from Cooper Biomedicals (Freehold, NJ). CMRL-1066 tissue culture medium, MEM, and HBSS were obtained from Gibco Laboratories (Grand Island, NY). Recombinant human IL $1 \beta(1,000 \mathrm{U} / \mathrm{ml})$ was obtained from Cistron Biotechnology (Pine Brook, NJ). L- $\left.{ }^{35} \mathrm{~S}\right]$ Methionine $(1 \mathrm{mCi} / \mathrm{ml})$ was purchased from New England Nuclear (Boston, MA). ${ }^{35}$ S-translabel $(10 \mathrm{mCi} / \mathrm{ml})$ was obtained from ICN Radiochemicals (Costa Mesa, CA). Actinomycin $\mathrm{D}$, cycloheximide, puromycin, and anisomycin were purchased from Sigma Chemical Co. (St. Louis, MO).

Islet isolation and culture. Islets were isolated from three to eight rats fed ad lib. by collagenase digestion, as previously described (18). Briefly, on the day before each experiment, pancreases were inflated 
with HBSS and the tissue was minced and digested with collagenase (5 $\mathrm{mg} / \mathrm{ml}$ ) for $15-17 \mathrm{~min}$ at $39^{\circ} \mathrm{C}$. The islets were then separated on discontinuous Ficoll density gradients and selected with a stereomicroscope to exclude any contaminating tissues. Islets were cultured overnight in an atmosphere of $95 \%$ air $/ 5 \% \mathrm{CO}_{2}$ at $37^{\circ} \mathrm{C}$ in $2.5 \mathrm{ml}$ complete tissue culture medium (CMRL-1066 containing $5 \mathrm{mM}$ Dglucose, $1 \%$ L-glutamine, $5 \%$ heat-inactivated fetal bovine serum, $0.5 \%$ penicillin, and $0.5 \%$ streptomycin).

Exposure of islets to IL 1 . Islets which had been cultured overnight in CMRL-1066 were distributed into two or more sterile Petri dishes, and $2.5 \mathrm{ml}$ fresh CMRL medium was added. IL 1 was added to some dishes at a concentration between 0.1 and $10 \mathrm{U} / \mathrm{ml}$. Vehicle for IL 1 (PBS containing $2 \mu \mathrm{M}$ DTT and $0.1 \% \mathrm{BSA}, \mathrm{pH} 7.2$ ) was added to other dishes as control. The islets were then cultured in an atmosphere of $95 \%$ air $/ 5 \% \mathrm{CO}_{2}$ at $37^{\circ} \mathrm{C}$. In some experiments islets were cultured continuously with IL 1 for up to $18 \mathrm{~h}$. In other experiments islets were cultured with IL 1 for shorter periods $(1,3$, or $5 \mathrm{~h}$ ). At the end of the 1-, 3-, or 5-h pulse with IL 1, the islets were washed five times with CMRL-1066 medium to remove the IL 1 , and the medium was replaced with fresh CMRL-1066 medium containing no IL 1 . The islets were then cultured under an atmosphere of $95 \%$ air $/ 5 \% \mathrm{CO}_{2}$ at $37^{\circ} \mathrm{C}$ for up to $17 \mathrm{~h}$. In all experiments, control islets were washed and handled in a manner identical to that of the IL 1-treated islets.

Studies with actinomycin $D$, cycloheximide, puromycin, and anisomycin. Actinomycin D and cycloheximide were prepared as $1-\mathrm{mM}$ stocks in DMSO. Puromycin was prepared as a 250 -mM stock in DMSO. Anisomycin was prepared as a $50-\mathrm{mM}$ stock in distilled water. In the experimental protocols, $1 \mu \mathrm{l}$ of the appropriate stock was added per $1 \mathrm{ml}$ CMRL-1066 medium to achieve a final actinomycin D concentration of $1 \mu \mathrm{M}$, a final cycloheximide concentration of $1 \mu \mathrm{M}$, a final puromycin concentration of $500 \mu \mathrm{M}$, or a final anisomycin concentration of $50 \mu \mathrm{M}$. DMSO (vehicle for actinomycin D, cycloheximide, and puromycin) and distilled water (vehicle for anisomycin) were added to the appropriate control dishes. In these experiments, the inhibitors of RNA and protein synthesis were present either during the 1-h pulse with IL 1 or during the culture period after the 1-h IL 1 pulse.

Measurement of glucose-induced insulin secretion. At the end of the culture period, islets were washed in modified Krebs-Ringer bicarbonate buffer (KRBB: ${ }^{1} 25 \mathrm{mM}$ Hepes, $115 \mathrm{mM} \mathrm{NaCl}, 24 \mathrm{mM} \mathrm{NaHCO}_{3}, 5$ $\mathrm{mM} \mathrm{KCl}, 1 \mathrm{mM} \mathrm{MgCl}, 2.5 \mathrm{mM} \mathrm{CaCl}_{2}, \mathrm{pH} 7.4$ ) containing $3 \mathrm{mM}$ glucose and $0.05 \%$ BSA. Groups of 20 islets were counted into $10 \times 75$ $\mathrm{mm}$ siliconized borosilicate test tubes, preincubated for $30 \mathrm{~min}$ in $\mathrm{KRBB}$ containing $3 \mathrm{mM}$ glucose and $0.05 \% \mathrm{BSA}$, and then incubated for $30 \mathrm{~min}$ in fresh KRBB ( 3 or $16.5 \mathrm{mM}$ glucose, $0.05 \%$ BSA). Preincubation and incubation were performed at $37^{\circ} \mathrm{C}$ under an atmosphere of $95 \%$ air $/ 5 \% \mathrm{CO}_{2}$. Insulin content of the incubation medium was measured by double-antibody RIA as described elsewhere (7).

Purification of islet $\beta$-cells by autofluorescence-activated cell sorting (FACS). Isolated islets were dispersed into individual cells by treatment with dispase, as previously described $(19,20)$. The freshly dissociated cells were subjected to autofluorescence-activated cell sorting using a FACS-IV instrument $(19,20)$. An argon laser illuminated the cells at $488 \mathrm{~nm}$, and emission was monitored at $510-550 \mathrm{~nm}$. The cell sorting process yields two purified cell populations $(19,20)$. One population consists of highly purified $\beta$-cells $(>90 \%)(19,20)$. The second population is predominantly $\alpha$-cells (70\%), but also contains some $\delta$-cells and a few $\beta$-cells $(19,20)$.

Effect of IL 1 pretreatment (18 h) on glucose-induced insulin secretion from purified $\beta$-cells. Purified $\beta$-cells were incubated with IL 1 (5 $\mathrm{U} / \mathrm{ml}$ ) or vehicle for $18 \mathrm{~h}$ in CMRL-1066 tissue culture medium (5 $\times 10^{5}$ cells/dish). After the 18 -h pretreatment, the cells were counted with a hemocytometer. The $\beta$-cells were then aliquoted into $1-\mathrm{ml}$ Petri

1. Abbreviations used in this paper: KRBB, Krebs-Ringer bicarbonate buffer. dishes $(\sim 8,000$ cells/dish). A volume $(1 \mathrm{ml})$ of KRBB supplemented with $0.05 \%$ BSA, glucose ( 3 or $16.5 \mathrm{mM})$, and theophylline $(5 \mathrm{mM})$ was then added. The cells were incubated at $37^{\circ} \mathrm{C}$ for $3 \mathrm{~h}$. The cells and supernatants were then transferred to microcentrifuge tubes $(1.5 \mathrm{ml})$ and centrifuged, and the supernatant was removed. The insulin content of the supernatant was then determined by RIA (7).

Measurement of islet insulin content. Islets were treated with IL 1 ( 5 $\mathrm{U} / \mathrm{ml}$ ) or vehicle for $1,5,9$, or $18 \mathrm{~h}$, as described above. Islets from the control and IL 1-treated groups were then washed and resuspended in KRBB ( $3 \mathrm{mM}$ glucose, $0.05 \%$ BSA), and counted into $10 \times 75 \mathrm{~mm}$ borosilicate tubes ( 20 islets/tube). The KRBB was removed from the islets with a pipetman; acid-ethanol $(1 \mathrm{ml})$ was added to each tube (7); and the islets were incubated at $4^{\circ} \mathrm{C}$ for $48 \mathrm{~h}$. The supernatant was then removed, and serial dilutions of the supernatants were prepared. Insulin content of the acid-alcohol extracts was measured by double-antibody RIA (7).

Measurement of islet preproinsulin mRNA levels. Isolated islets were incubated with IL $1(5 \mathrm{U} / \mathrm{ml})$ or vehicle for $1,3,5,9$, or $18 \mathrm{~h}$. At the end of the treatment period, total islet RNA was prepared using guanidine thiocyanate as described (21). Total preproinsulin mRNA was measured by dot hybridization. Aliquots $(5 \mu \mathrm{g})$ of total islet RNA were applied to nylon membranes using a vacuum manifold. Membranes were baked and prehybridized $(22)$ at $60^{\circ} \mathrm{C}$ for $4 \mathrm{~h}$. Blots were hybridized with a uniformly labeled RNA complementary to rat insulin I mRNA as described (22).

Protein synthesis assay. Islets were incubated with IL 1 for $1 \mathrm{~h}$ as described above. The islets were then washed with CMRL-1066 medium, placed in sterile Petri dishes, and cultured for an additional $8 \mathrm{~h}$ in CMRL-1066 medium containing cycloheximide $(0.1-10 \mu \mathrm{M})$ and $\mathrm{L}-\left[{ }^{35} \mathrm{~S}\right]$ methionine $(33 \mu \mathrm{Ci} / \mathrm{ml})$. After the 8 -h culture period, the islets were distributed ( 20 islets/tube) into $1.5-\mathrm{ml}$ polyallomer tubes. The islets were washed three times with fresh CMRL-1066 medium to remove unincorporated radiolabel. $500 \mu \mathrm{l}$ ice-cold TCA (10\% wt/vol) was then added to precipitate islet protein. The islets were sequentially washed and pelleted three times with the ice-cold TCA solution. The ${ }^{35} \mathrm{~S}$ content of the pellet was then determined by liquid scintillation spectrometry (model 1500; Packard Instruments, Downers Grove, IL).

Preparation of samples for two-dimensional electrophoresis. Isolated islets were cultured for $8 \mathrm{~h}$ in 1-ml Petri dishes containing methionine-free MEM supplemented with IL $1(5 \mathrm{U} / \mathrm{ml})$ or the control vehicle. After $8 \mathrm{~h},{ }^{35} \mathrm{~S}$-translabel $(1 \mathrm{mCi})$ was added to each dish, and the islets were cultured for an additional hour. The labelled islets were then washed in ice-cold KRBB ( $3 \mathrm{mM}$ glucose, no BSA) three times to remove unincorporated radiolabel. Groups of 200 islets were placed into 1.5-ml Eppendorf tubes, and $100 \mu$ l boiling SDS solution (23) was added. Samples were placed in a boiling water bath for $5 \mathrm{~min}$ and then cooled on ice. DNase/RNase solution $(10 \mu \mathrm{l})$ was added (23), and the samples were kept on ice for an additional $5 \mathrm{~min}$. Samples were then snap-frozen in liquid $\mathrm{N}_{2}$ and lyophilized.

Two-dimensional electrophoresis of islet proteins. Lyophilized samples were solubilized in $9 \mathrm{M}$ urea and separated by two-dimensional polyacrylamide gel electrophoresis as described (24). Isoelectric focusing was performed in the first dimension in a 50:50 mixture of ampholyte 3/10 Bio-Lyte (Bio-Rad Laboratories, Richmond, CA) and Servalyt 3-10 (Serva Biochemicals, Westbury, NY). SDS-PAGE was performed in the second dimension with $10 \%$ gels. After electrophoresis, the gels were dried and exposed to $x$-ray film. Three independent experiments performed in quadruplicate yielded 12 autoradiograms for the control samples and 12 autoradiograms for the IL 1-treated samples. Densitometric scanning of individual spots was performed with a spectrophotometer (model DU-8; Beckman Instruments, Inc., Fullerton, CA) equipped with a gel scanning attachment. To correct for slight differences in the amounts of total radioactivity loaded onto each of the gels, all optical density measurements from each autoradiogram were normalized to the optical density of actin in the autoradiogram. This permitted quantitative comparisons of relative spot intensities among autoradiograms. 


\section{Results}

Effect of continuous IL 1 exposure (18 h) on glucose-induced insulin secretion from isolated islets. Islets were cultured with IL $1(0.1-10 \mathrm{U} / \mathrm{ml})$ for $18 \mathrm{~h}$, as described in Methods. At the end of this period, glucose-induced insulin secretion was measured during a 30-min incubation in KRBB containing glucose ( 3 or $16.5 \mathrm{mM}$ ) and $0.05 \%$ BSA. Fig. $1 A$ demonstrates that continuous pretreatment of islets with IL 1 for $18 \mathrm{~h}$ inhibited glucose-induced insulin secretion and that this effect depended on the concentration of IL 1 . The maximal degree of inhibition (95\%) was achieved at an IL 1 concentration of 5 $\mathrm{U} / \mathrm{ml}$. That concentration of IL 1 was therefore used in all subsequent experiments. The effect of IL 1 was manifest only on glucose-induced (16.5 mM glucose) insulin secretion. No effect of IL 1 pretreatment on basal ( $3 \mathrm{mM}$ glucose) insulin secretion was observed (not shown). Fig. $1 B$ depicts the time course of the effect of IL 1 pretreatment on glucose-induced
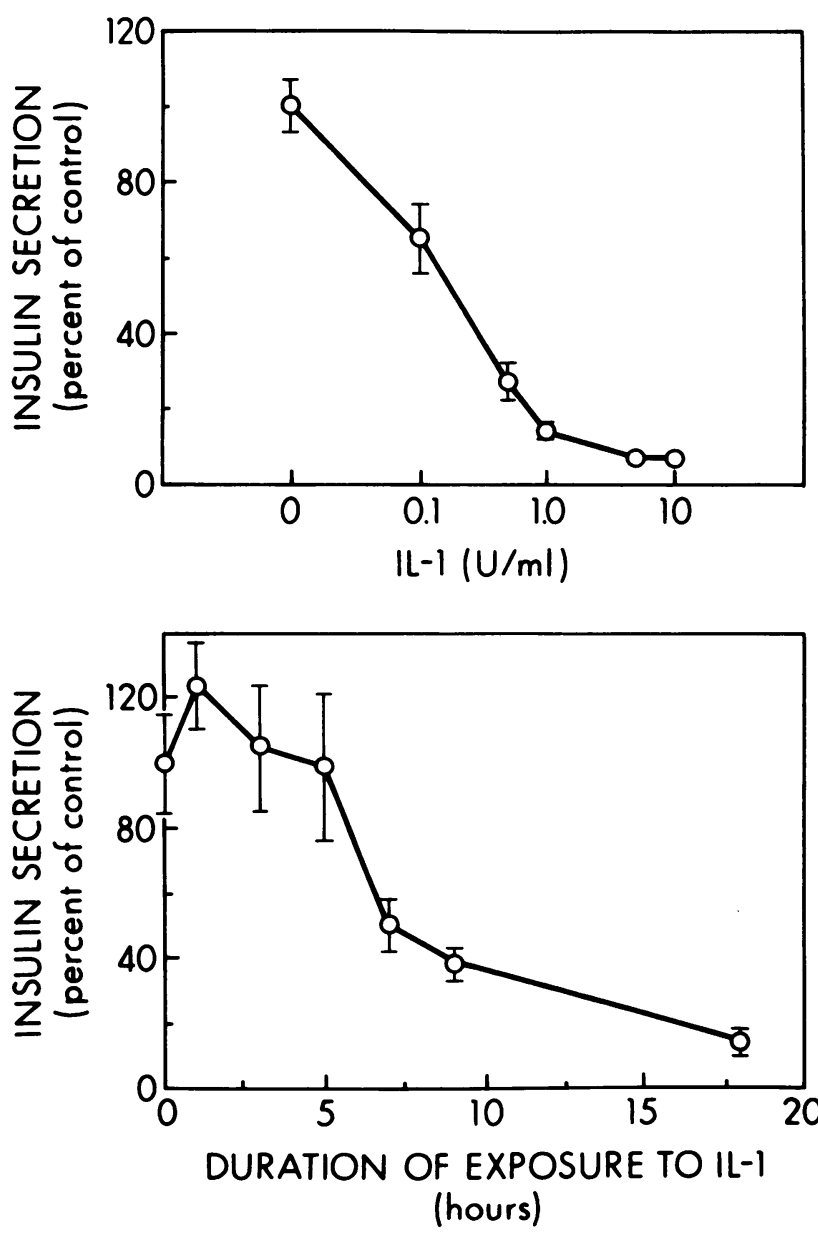

Figure 1. Effect of IL 1 pretreatment on glucose-induced insulin secretion by isolated islets. Isolated islets were pretreated $\left(37^{\circ} \mathrm{C}\right)$ with IL $1(0.1-10 \mathrm{U} / \mathrm{ml})$ or control for $1-18 \mathrm{~h}$, as described in Methods. At the end of the pretreatment period, glucose-induced insulin secretion was measured during a 30 -min challenge with $16.5 \mathrm{mM}$ glucose in KRBB. (Top) Concentration dependence of the effect of IL 1 pretreatment for $18 \mathrm{~h}$. (Bottom) Time course of the IL 1 effect at an IL 1 concentration of $5 \mathrm{U} / \mathrm{ml}$. Results are the mean \pm SEM of data from three independent experiments.

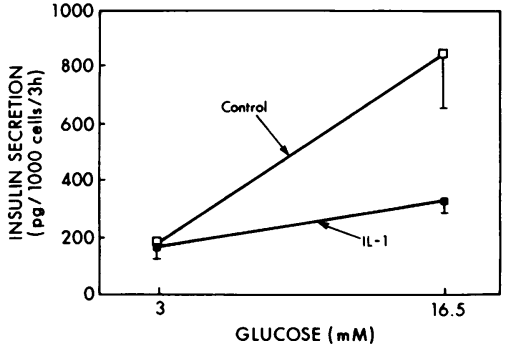

Figure 2. Effect of IL 1 pretreatment $(18 \mathrm{~h})$ on glucose-induced insulin secretion from FACSpurified $\beta$-cells. Isolated islets were dispersed into single cells and a purified $\beta$-cell population was obtained by fluorescence-activated cell sorting was per-

formed. The purified $\beta$-cells were incubated with IL $1(5 \mathrm{U} / \mathrm{ml})$ or the control vehicle for 18 hours, as described in Methods and glucose-induced insulin secretion was then measured during a 3-h incubation in KRBB $(0.05 \%$ BSA, 3 or $16.5 \mathrm{mM}$ glucose) supplemented with $5 \mathrm{mM}$ theophylline.

insulin secretion. Continuous pretreatment of islets with IL 1 for up to $5 \mathrm{~h}$ did not influence glucose-induced insulin secretion significantly when measured after the pretreatment period. Continuous pretreatment of islets with IL 1 for longer times $(7-18 \mathrm{~h})$ did, however, result in significant inhibition $(P$ $<0.05$ ) of glucose-induced insulin secretion.

Effect of IL 1 on insulin secretion from FACS-purified $\beta$-cells. The islet is a heterogeneous cell population which contains a variety of endocrine and nonendocrine cell types, each of which represents a potential target for IL 1 . We sought to determine whether the ability of IL 1 to inhibit insulin secretion from islets was the result of a direct effect of the cytokine on the $\beta$-cell or whether it required an intermediary islet cell which, when stimulated by IL 1 , released products that inhibited $\beta$-cell secretion. A highly purified $(>90 \%)$ population of $\beta$-cells was obtained by FACS of dispersed islets cells $(19,20)$. After pretreatment of such purified $\beta$-cell populations with IL 1 for $18 \mathrm{~h}$, glucose-induced insulin secretion was measured as in Methods. Fig. 2 demonstrates that insulin secretion from the FACS-purified $\beta$-cells at a basal glucose concentration ( 3 $\mathrm{mM}$ ) was unaffected by $18-\mathrm{h}$ IL 1 pretreatment but that insulin secretion at a stimulatory glucose concentration $(16.5 \mathrm{mM})$ was significantly impaired. These results are identical to those obtained in studies examining the effect of IL 1 on insulin secretion from intact isolated islets (7), and they suggest that IL 1 exerts its effects on insulin secretion through a direct interaction with the $\beta$-cell rather than through an action on an intermediary cell.

Effect of IL 1 treatment on islet content of insulin and of preproinsulin $m R N A$. To determine whether the inhibition of insulin secretion induced by IL 1 (Fig. $1, A$ and $B$ ) was the result of decreased insulin biosynthesis, isolated islets were treated with IL 1 or vehicle for $1,5,9$, or $18 \mathrm{~h}$. At the end of that period, islet content of insulin and of preproinsulin mRNA levels was measured, as described in Methods. Table I demonstrates that preproinsulin mRNA levels were unaffected by treatment with IL 1 for 1,5 , or $9 \mathrm{~h}$. After $18 \mathrm{~h}$ of IL 1 treatment, preproinsulin mRNA levels were reduced somewhat $(36 \%)$, but this effect developed long after the inhibition of insulin secretion induced by IL 1 . The latter effect was manifest after only $7 \mathrm{~h}$ and was nearly fully developed after $9 \mathrm{~h}$ of treatment (Fig. $1 A$ ). In addition, islet insulin content was completely unaffected throughout the entire $18-\mathrm{h}$ treatment 
Table I. Effect of IL-1 Treatment on Insulin Content and Preproinsulin mRNA Levels in Isolated Islets

\begin{tabular}{ccc}
\hline $\begin{array}{c}\text { Duration of } \\
\text { exposure to IL 1 }\end{array}$ & Insulin content & Preproinsulin mRNA \\
\hline$h$ & \multicolumn{3}{c}{ \% of control } \\
1 & $114 \pm 10$ & $109 \pm 23$ \\
5 & $95 \pm 10$ & $127 \pm 35$ \\
9 & $92 \pm 14$ & $112 \pm 17$ \\
18 & $94 \pm 4$ & $64 \pm 8$ \\
\hline
\end{tabular}

Isolated islets were incubated with IL $1(5 \mathrm{U} / \mathrm{ml})$ or control for 1,5 , 9 , or $18 \mathrm{~h}$. Total insulin content and preproinsulin mRNA were then quantitated as described in Methods. Data are expressed as a percentage of control and represent the mean \pm SEM of five to six observations from two independent experiments. All differences are statistically nonsignificant.

period with IL 1. It therefore appears that the inhibition of insulin induced by IL 1 treatment $(9-18 \mathrm{~h})$ does not involve a reduction in islet insulin content or a defect in insulin biosynthesis.

Effect of a brief pulse of IL 1 exposure on glucose-induced insulin secretion measured at later time points. The data represented in Fig. $1 B$ demonstrate that the inhibitory effect of IL 1 on insulin secretion requires $>5 \mathrm{~h}$ to develop. Two different mechanisms of IL 1 action could have accounted for this finding. One possibility was that islets must be continuously challenged with IL 1 for $>5 \mathrm{~h}$ before they are "committed" to a state of reduced insulin secretion. A second possibility was that islets are "committed" to inhibition of insulin secretion soon after they are exposed to IL 1 but that $>5 \mathrm{~h}$ are required for the inhibitory effect to develop. The latter possibility was tested by exposing islets to IL 1 for short time periods $(1,3$, or $5 \mathrm{~h}$ ) and then removing the IL 1 from the medium. After this $1-, 3-$, or 5-h pulse with IL 1 , the islets were maintained in culture as described in Methods. Glucose-induced insulin secretion was then measured after various intervals. Fig. $3 \mathrm{dem}-$ onstrates that exposure of islets to IL 1 for only $1 \mathrm{~h}$ followed by incubation in IL 1 -free medium resulted in a time-dependent diminution of insulin secretion. The time course over which the diminution of insulin secretion developed was nearly identical to that observed with continuous IL 1 treatment (Fig. $1 B$ ). The 1-h pulse with IL 1 did not significantly influence insulin secretion at culture times $<4 \mathrm{~h}$ after the 1 -h pulse with IL 1. Thereafter, glucose-induced insulin secretion decreased dramatically. The maximal degree of inhibition of insulin secretion $(60 \%)$ occurred $8 \mathrm{~h}$ after the 1 -h pulse with IL 1 , and this effect persisted throughout the duration of the experiment $(18 \mathrm{~h})$.

Effect of a pharmacologic inhibitor of DNA transcription on IL 1 -induced inhibition of insulin secretion. The finding that a brief pulse with IL 1 was sufficient to produce the cytokine's inhibitory effect on insulin secretion offered a model for studying IL 1 action. Because this model involves exposure of islets to IL 1 for only $1 \mathrm{~h}$, followed by measurement of glucose-induced insulin secretion at later times, it is useful for identifying the early biochemical responses to IL 1 that ultimately lead to inhibition of insulin secretion more than five hours later. To

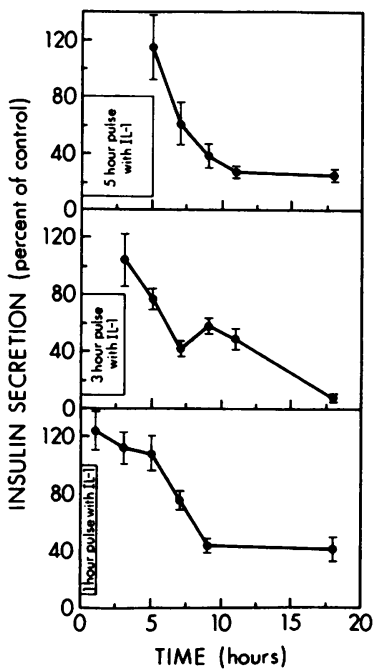

determine whether the inhibitory effect of IL 1 on insulin secretion required DNA transcription, we examined the influence of a pharmacologic inhibitor of mRNA synthesis (actinomycin D) on IL 1-induced inhibition of insulin secretion in this model (Fig. 4). Islets were exposed to IL 1 for 1 hour; the IL 1 was then removed; and the islets were cultured for an additional $8 \mathrm{~h}$. Glucose-induced insulin secretion was then measured. Actinomycin $\mathrm{D}(1 \mu \mathrm{M})$ was present either during the 1-h pulse with IL $1(0-1 \mathrm{~h})$ or during the subsequent $8-\mathrm{h}$ culture period in the absence of IL 1 (1-9 h). Fig. 4 demonstrates that actinomycin D completely prevented IL 1 -induced inhibition of insulin secretion when the agent was present during the 1-h pulse with IL 1 . When actinomycin D was added after the IL 1 pulse, however, it did not prevent the inhibitory effect of IL 1 . These data indicate that the development of the inhibitory effect of IL 1 on insulin secretion requires that new mRNA synthesis occurs within the first hour of exposure to IL 1 .

Effect of pharmacologic inhibitors of $M R N A$ translation on IL 1 -induced inhibition of insulin secretion. The finding that actinomycin D prevented development of IL 1-induced inhibi-

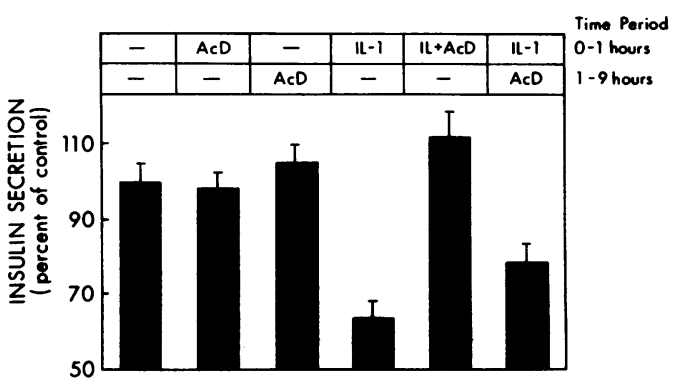

Figure 4. Effect of actinomycin D on IL 1-induced inhibition of insulin secretion. Islets were pulsed with IL $1(5 \mathrm{U} / \mathrm{ml})$ for $1 \mathrm{~h}$. After this $1-\mathrm{h}$ pulse with IL 1 , the islets were washed and suspended in fresh CMRL-1066 medium containing no IL 1 . The islets were cultured for an additional $8 \mathrm{~h}$, and glucose-induced insulin secretion was then measured, as described in Methods. Actinomycin $\mathrm{D}(1 \mu \mathrm{M})$ was present during the $1-\mathrm{h}$ pulse with IL $1(0-1 \mathrm{~h})$, or was added after the 1-h pulse with IL 1 (1-9 $\mathrm{h})$. Results are expressed as the mean \pm SEM of data from three independent experiments. 
tion of insulin secretion suggested that the inhibitory effect of IL 1 might be mediated by the synthesis of new protein(s). This possibility was tested by examining the influence of the mRNA translational inhibitor cycloheximide on IL 1-induced inhibition of insulin secretion (Fig. 5). Islets were pulsed with IL 1 for $1 \mathrm{~h}$. After the IL 1 had been removed from the medium, cycloheximide $(1 \mu \mathrm{M})$ was added. The islets were then cultured for $8 \mathrm{~h}$ in the presence of cycloheximide. Glucose-induced insulin secretion was measured at the end of this period. Fig. 5 demonstrates that addition of cycloheximide to islets after the 1-h pulse with IL 1 completely prevented development of IL 1 -induced inhibition of insulin secretion. In separate experiments, other pharmacologic inhibitors of protein synthesis were examined under these conditions. Both puromycin (500 $\mu \mathrm{M})$ and anisomycin $(50 \mu \mathrm{M})$ prevented development of IL 1 -induced inhibition of insulin secretion when added to islets after the 1-h pulse with IL 1 (not shown). Pharmacologic inhibition of protein synthesis during the 1 hour pulse with IL 1 failed to prevent development of IL 1-induced inhibition of insulin secretion if the inhibitors were removed during the subsequent incubation period (not shown). The inhibitory effect of IL 1 on insulin secretion therefore appears to require: (a) a transcriptional phase (blocked by actinomycin D but not by cycloheximide) that occurs within the first hour of exposure to IL 1 and $(b)$ a translational phase (blocked by cycloheximide but not by actinomycin $D$ ) that occurs after the first hour of exposure to IL 1 .

To determine the extent to which protein synthesis must be inhibited to prevent the inhibitory effect of IL 1 on insulin secretion, islets were exposed to IL 1 for $1 \mathrm{~h}$, washed to remove the IL 1 , and then suspended in CMRL-1066 medium containing $\mathrm{L}-\left[{ }^{35} \mathrm{~S}\right]$ methionine $(33.3 \mu \mathrm{Ci} / \mathrm{ml})$ and various concentrations of cycloheximide $(0.1-10 \mu \mathrm{M})$. The islets were then cultured for $8 \mathrm{~h}$, and total protein synthesis during this 8 -h culture period was measured as described in Methods. Glucose-induced insulin secretion was also measured in parallel experiments performed under identical conditions. Fig. 6 demonstrates that islet protein synthesis decreased and insulin secretion increased in IL 1-treated islets as approximately concordant functions of increasing cycloheximide concentrations.

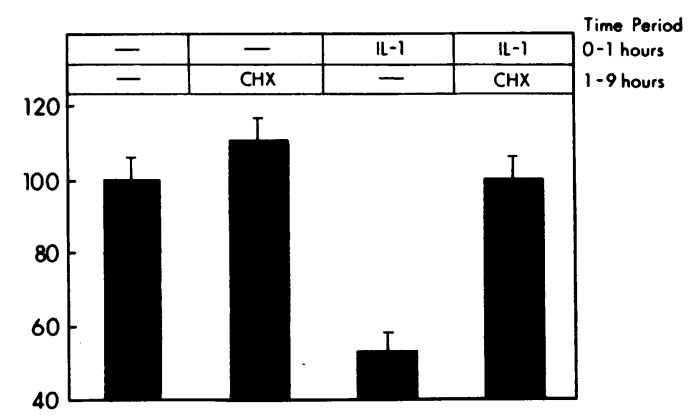

Figure 5. Effect of cycloheximide on IL 1-induced inhibition of insulin secretion. Islets were pulsed with IL $1(5 \mathrm{U} / \mathrm{ml})$ for $1 \mathrm{~h}$. After the 1-h pulse with IL 1 , the islets were washed and resuspended in fresh CMRL-1066 medium containing no IL 1 . The islets were cultured for an additional $8 \mathrm{~h}$, and glucose-induced insulin secretion was then measured, as described in Methods. Cycloheximide $(1 \mu \mathrm{M})$ was added to cultures after the 1-h pulse with IL 1 (1-9 h). Results are expressed as the mean \pm SEM of data from eight independent experiments.

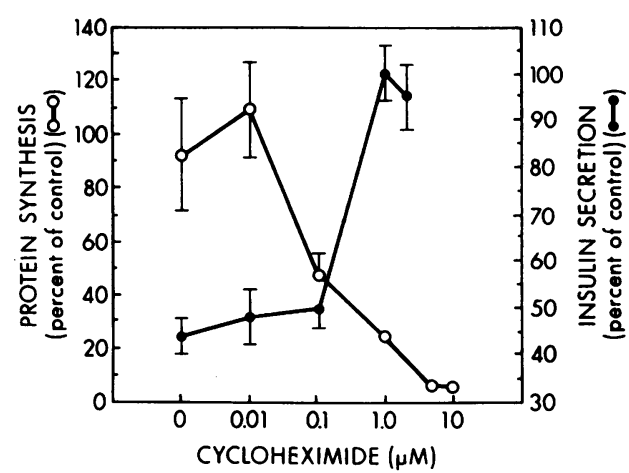

Figure 6. Effect of cycloheximide on islet protein synthesis and IL 1induced inhibition of insulin secration. Islets were pulsed with IL 1 for $1 \mathrm{~h}$. After the $1-\mathrm{h}$ pulse with IL 1 , the islets were washed and resuspended in fresh CMRL-1066 medium containing cycloheximide $(0.1-10 \mu \mathrm{M}), \mathrm{L}-\left[{ }^{35} \mathrm{~S}\right] \mathrm{methionine}(33.3 \mu \mathrm{Ci} / \mathrm{ml})$, and no IL 1 . The islets were cultured for an additional $8 \mathrm{~h}$. Protein synthesis and glucose-induced insulin secretion were then measured, as described in Methods. Results are expressed as the mean \pm SEM of data from three independent experiments.

Comparison of the concentration of cycloheximide required to prevent development of IL 1-induced inhibition of insulin secretion $\left(\mathrm{EC}_{50}=0.3 \mu \mathrm{M}\right)$ to that required to inhibit protein synthesis $\left(\mathrm{IC}_{50}=0.1 \mu \mathrm{M}\right)$ suggests that protein synthesis must be inhibited by $\sim 80 \%$ to prevent development of IL 1 -induced inhibition of insulin secretion (Fig. 6).

Two-dimensional gel electrophoresis of proteins from IL 1-treated islets. The pharmacologic experiments described above suggested that the inhibition of insulin secretion by IL 1 requires gene transcription and the translation of the resultant mRNA into protein products. The technique of two-dimensional (2-D) gel electrophoresis was therefore employed to identify directly islet proteins whose expression is modulated by IL 1 . Figs. 7 and 8 demonstrate that IL 1 influenced the expression of three proteins in islets. IL 1 augmented by $>2.5$-fold $(P<0.02)$ the expression of a protein with a molecular mass of $\sim 65 \mathrm{kD}$ and a pl of $\sim 6.5$ (Fig. $8 \mathrm{~A}$ ). This protein appeared to consist of two isomeric forms that differed slightly in mobility on SDS-PAGE. The relative abundancies of two other proteins, each with a pl of $\sim 5.0$ and approximate molecular masses of 50 and $45 \mathrm{kD}$, were decreased in the IL 1-treated islets by $59(P<0.002)$ and $31 \%(0.1>P>0.05)$, respectively (Fig. $8 \mathrm{~B}$ ). Table II summarizes the approximate molecular weight and isoelectric point, the relative abundance compared with control, and the statistical significance of the difference between control and IL 1-treated samples for each protein whose expression was modulated by IL 1 . The number $(1,2$, or 3$)$ assigned to each protein listed in Table II specifies the location of the protein in the autoradiograms shown in Figs. 7 and 8.

\section{Discussion}

These results confirm the finding by our group $(7,16)$ and others $(4-6,8-11)$ that IL 1 is a potent inhibitor of glucose-induced insulin secretion from isolated islets and that this effect develops in a time and IL 1 concentration-dependent manner (Fig. 1, $A$ and $B$ ). It is also demonstrated for the first time here 


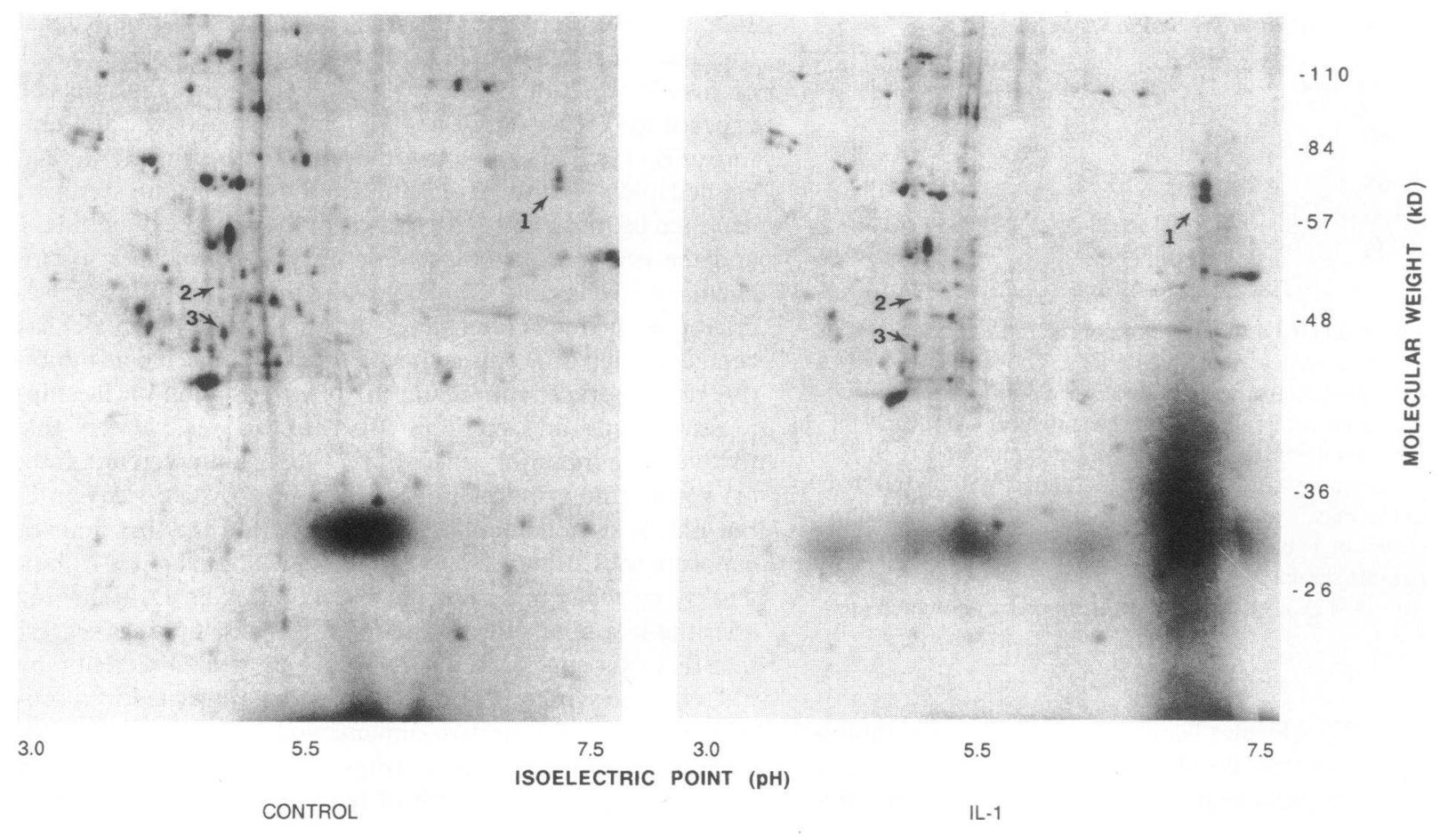

Figure 7. Two-dimensional gel electrophoresis of proteins from IL 1-treated islets. Isolated islets were labeled with ${ }^{35}$ S]methionine in methionine-free MEM supplemented with IL $1(5 \mathrm{U} / \mathrm{ml})$ or vehicle, as described in Methods. Two-dimensional gel electrophoresis was then performed. (Left) Electrophoretic pattern of proteins obtained from islets exposed to vehicle. (Right) Electrophoretic pattern of proteins obtained from islets exposed to IL 1 . These autoradiograms are representative of three independent experiments performed in quadruplicate. Numbered arrows designate proteins whose expression was found to be modulated by IL 1 in a statistically significant manner and allow cross-referencing to Fig. 8 and to the statistical analysis displayed in Table II.

that IL 1 inhibits insulin secretion from a highly purified $\beta$-cell population obtained by FACS. This is the only demonstration of which we are aware that IL 1 influences insulin secretion by a $\beta$-cell population purified from normal islets. This result strongly suggests that IL 1 exerts its effect on insulin secretion by a direct interaction with the $\beta$-cell rather than by an action on an intermediary cell. This conclusion is also supported by Hammonds's recent demonstration that an insulin-secreting $\beta$-cell line derived from hamster insulinomas (HIT-T15) possesses specific receptors for IL 1 and that IL 1 inhibits glucoseinduced insulin secretion from these tumor cells (25).

To determine whether the inhibition of insulin secretion induced by IL 1 in our 18-h experimental design could be attributed to a defect in insulin biosynthesis, we examined islet preproinsulin mRNA levels. A comparison of the time dependence of the IL 1 effects on insulin secretion (Fig. $1 A$ ) and
A

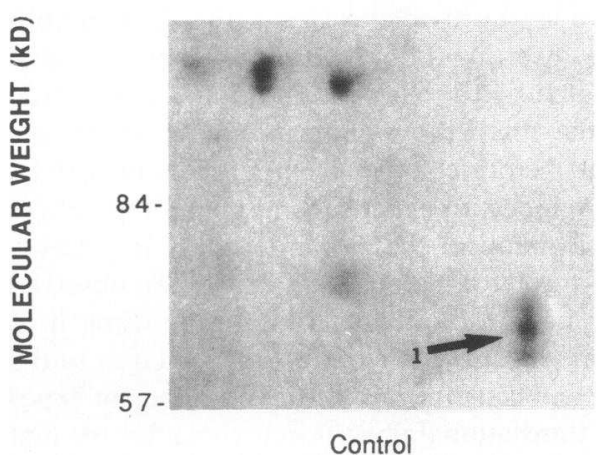

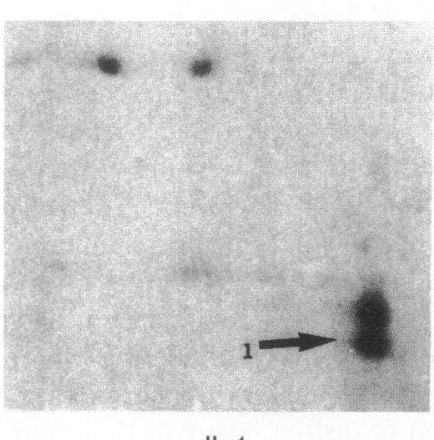

IL-1

B

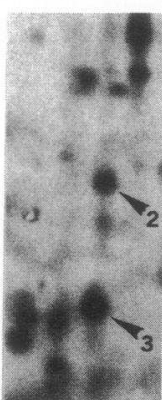

Control

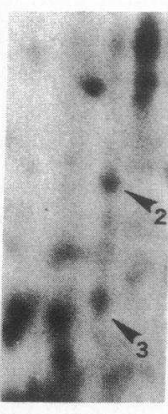

IL-1

Figure 8. Two-dimensional gel electrophoresis of proteins from IL 1-treated islets. These photographs represent magnifications of the areas of the autoradiograms where IL 1 was observed to influence the expression of proteins (see Fig. 7). Numbered arrows allow cross-referencing of the designated proteins to the statistical analysis displayed in Table II. 
Table II. Modulation of Protein Synthesis by IL I

\begin{tabular}{ccccc}
\hline Protein & Molecular mass & pI & Optical density & Statistical significance \\
\hline & $k D$ & & \% of control & \\
1 & 65 & 6.5 & $253 \pm 62$ & $0.02>p$ \\
2 & 50 & 5.0 & $41.4 \pm 5.7$ & $0.002>p$ \\
3 & 45 & 5.0 & $68.8 \pm 8.9$ & $0.1>p>0.05$ \\
\hline
\end{tabular}

Isolated islets were labeled with $\left[{ }^{35} \mathrm{~S}\right]$ methionine in the presence of IL $1(5 \mathrm{U} / \mathrm{ml})$ or vehicle as described in Methods. The table summarizes the approximate molecular mass and isoelectric point, the relative abundance compared with control, and the statistical significance of the difference between control and IL 1-treated samples for each of the three proteins whose expression was modulated by IL 1 and that are represented in Figs. 7 and 8 . The number $(1,2$, or 3$)$ assigned to each protein listed in Table II specifies the location of the protein in the autoradiograms shown in Figs. 7 and 8. Data are expressed as the mean $\pm \operatorname{SEM}(n=4-12)$. $p$ values were determined by two-tailed $t$ test.

preproinsulin mRNA levels (Table I) indicates that the inhibition of insulin secretion by IL 1 clearly occurs before any alterations in preproinsulin mRNA levels. This finding, coupled with the observation that total islet insulin content did not change during 18-h treatment with IL 1 (Table I), demonstrates that inhibition of insulin secretion by IL 1 is unlikely to involve reduction in the insulin available for secretion in the $\beta$-cell. The modest reduction of preproinsulin mRNA levels which occurs late in the time course $(18 \mathrm{~h})$ of exposure of islets to IL 1 has also been reported by Spinas et al. (26). Thus, whereas reduced insulin biosynthesis may play a role in the effects of IL 1 on insulin secretion and islet function following exposure times exceeding $18 \mathrm{~h}$, our results demonstrate that shorter exposures $(1-18 \mathrm{~h})$ of islets to IL 1 inhibit insulin secretion under conditions where islet insulin content is unaffected and by a mechanism which is independent of effects on insulin biosynthesis.

Perhaps the most striking finding of this study is that only brief periods ( $1 \mathrm{~h}$ ) of exposure of islets to IL 1 are required to induce commitment to a state of reduced glucose-induced insulin secretion that develops several hours later. Previous studies on the mechanism of action of IL 1 on islets have been confounded by the fact that the inhibitory effect of IL 1 requires several hours or days to develop, depending on the experimental design. That the inhibitory effects of IL 1 on islets develop rather slowly has made it difficult to link early biochemical events to the inhibition of insulin secretion which occurs hours later. Our finding that a 1-h exposure of islets to IL 1 is sufficient to inhibit insulin secretion $17 \mathrm{~h}$ after the IL 1 has been removed from the culture has two important implications. First, it demonstrates that biochemical events which mediate the inhibitory effect of IL 1 occur within the first hour of exposure; once these events occur, the islets are "committed" to develop a state of reduced insulin secretion several hours later. The observation that transitory exposure of the $\beta$-cell to IL 1 produces dramatic, sustained inhibition of insulin secretion strengthens the hypothesis that fluctuating concentrations of IL 1 in the endocrine pancreas may play an important role in the physiologic modulation of insulin secretion in vivo $(7,13)$. Second, this experimental model is well suited to the use of pharmacological probes to study signal transduction events which mediate the inhibitory effect of IL 1 on insulin secretion. Because this model requires that islets be exposed to IL 1 for only $1 \mathrm{~h}$, potential pharmacological inhibitors of IL 1 action can be tested during the 1-h pulse and then washed away with the IL 1 . Glucose-induced insulin secretion can then be measured 7-18 h later, in the absence of both IL 1 and the pharmacologic inhibitor. In this manner, early biochemical effects can be linked to the inhibition of insulin secretion occurring at later times. This feature of the model has been exploited to examine the effects of pharmacologic inhibitors of gene transcription and mRNA translation on the suppression of insulin secretion by IL 1 . In this way, we were able to divide the inhibitory effect of IL 1 on insulin secretion into: (a) a gene transcriptional phase (inhibited by actinomycin D but not by cycloheximide) occurring within the first hour of exposure to IL 1 and $(b)$ an mRNA translational phase (inhibited by cycloheximide but not by actinomycin D) occurring after the first hour of exposure to IL 1 . These findings suggest that IL 1 exerts its inhibitory influence on insulin secretion by inducing the synthesis of mRNA which is translated into protein(s). Moreover, the two-dimensional gel analysis of $\left[{ }^{35} \mathrm{~S}\right]-$ methionine-labeled proteins (Figs. 7 and 8 ) provides direct evidence that IL 1 is capable of modulating the expression of specific gene products in isolated islets.

Our findings indicate that relatively short $(9 \mathrm{~h})$ exposure of isolated islets to IL 1 can modulate the expression of specific proteins and that this effect results in reduced insulin secretion. While this manuscript was in preparation, Helqvist reported that very long ( $24 \mathrm{~h}$ ) exposure of islets to IL 1 induces the synthesis of proteins of $\sim 32,70$, and $80 \mathrm{kD}(27)$. These proteins were not identified, but it was suggested that they represent heat shock proteins, SOD, or other proteins involved in the functional response of the islet to oxidative stress and toxic free radical formation (27). It therefore appears that IL 1 exerts time-dependent effects on protein synthesis in islets. Short (1-9 h) exposure of islets to IL 1 enhances the expression of protein(s) which mediate the inhibition of insulin secretion induced by IL 1 , whereas long ( $24 \mathrm{~h}$ ) exposure of islets to IL 1 enhances the expression of proteins which may be involved in the functional response of the $\beta$-cell to the deleterious effects of the cytokine. Identification of the proteins induced by IL 1 after both short and long exposures may lead to a better understanding of the mechanisms that underlie the functional effects of IL 1 on the $\beta$-cell.

In summary, we have provided evidence that IL 1 inhibits insulin secretion by exerting a direct effect on the $\beta$-cell, and we have demonstrated that the inhibition of insulin secretion by IL 1 occurs in the absence of significant alterations in islet insulin content and before changes in preproinsulin mRNA levels. We have developed an experimental model that allows us to relate early biochemical changes induced by IL 1 to the inhibitory effect of the cytokine on insulin secretion observed at later times. We have exploited this model by using it to divide the inhibitory effect of IL 1 on insulin secretion into a transcriptional phase, occurring within the first hour of exposure to IL 1, and a translational phase, occurring after the first hour of exposure to IL 1. Finally, we have used the technique of two-dimensional gel electrophoresis to demonstrate directly that IL 1 modulates the expression of specific gene products in islets. 


\section{Acknowledgments}

We would like to thank Dr. Laszlo Koranyi for providing help with the dot hybridization for preproinsulin mRNA. We would also like to acknowledge the outstanding technical assistance provided by Joan Fink and Connie Marshall.

This work was supported in part by a Medical Scientist Training Program Grant T32 GM07200 (to J. H. Hughes) and National Institutes of Health grants DK-34388 and K04 DDK-01553 (to J. Turk), and DK-06181 (to M. L. McDaniel).

\section{References}

1. Gery, I., R. K. Gershon, and B. H. Waksman. 1972. Potentiation of the T-lymphocyte response to mitogens. J. Exp. Med. 136:128-142. 2. Dinarello, C. A., and S. M. Wolf. 1982. Molecular basis of fever in humans. Am. J. Med. 72:799-819.

3. Kampschmidt, R. F., H. F. Upchurch, C. L. Eddington, and L. A. Pulliam. 1973. Multiple biological activities of a partially purified leukocytic endogenous mediator. Am. J. Physiol. 224:530-533.

4. Mandrup-Poulsen, T., K. Bendtzen, J. H. Nielsen, G. Bendixen, and J. Nerup. 1985. Cytokines cause functional and structural damage to isolated islets of Langerhans. Allergy. 40:424-429.

5. Mandrup-Poulsen, T., K. Bendtzen, J. Nerup, J. Egeberg, and J. H. Nielsen. 1986. Mechanisms of pancreatic islet-cell destruction: dose-dependent cytotoxic effects of soluble mononuclear cell mediators on isolated islets of Langerhans. Allergy. 41:250-259.

6. Zawalich, W. S., and V. A. Diaz. 1986. Interleukin 1 inhibits insulin secretion from isolated perifused rat islets. Diabetes. 35:11191123.

7. Comens, P. G., B. A. Wolf, E. R. Unanue, P. E. Lacy, and M. L. McDaniel. 1987. Interleukin 1 is potent modulator of insulin secretion from isolated rat islets of Langerhans. Diabetes. 36:963-970.

8. Sandler, S., A. Andersson, and C. Hellerstrom. 1987. Inhibitory effects of interleukin 1 on insulin secretion, insulin biosynthesis, and oxidative metabolism of isolated rat pancreatic pislets. Endocrinology. 121:1424-1431.

9. Mandrup-Poulsen, T., K. Bendtzen, J. Nerup, C. A. Dinarello, M. Svenson, and J. H. Nielsen. 1986. Affinity-purified human interleukin 1 is cytotoxic to isolated islets. Diabetologia. 29:63-67.

10. Rabinovitch, A., C. Pukel, and H. Baquerizo. 1988. Interleukin 1 inhibits glucose-modulated insulin and glucagon secretion in rat islet monolayer cultures. Endocrinology. 122:2393-2398.

11. Pukel, C., H. Baquerizo, and A. Rabinovitch. 1988. Destruction of rat islet cell monolayers by cytokines: synergistic interactions of interferon- $\gamma$, tumor necrosis factor, lymphotoxin, and interleukin 1. Diabetes. 37:133-136.

12. Nerup, J., T. Mandrup-Poulsen, and J. Molvig. 1987. The HLA-IDDM association: implications for etiology and pathogenesis of IDDM. 1987. Diabetes Metab. Rev. 3:779-802.

13. McDaniel, M. L., J. H. Hughes, B. A. Wolf, R. A. Easom, and J.
Turk. 1988. Descriptive and mechanistic considerations of interleukin 1 and insulin secretion. Diabetes. 37:1311-1315.

14. Wolf, B. A., J. H. Hughes, J. Florholmen, J. Turk, and M. L. McDaniel. 1989. Interleukin 1 inhibits glucose-induced $\mathrm{Ca}^{2+}$ uptake by islets of Langerhans. FEBS (Fed. Eur. Biochem. Soc.) Lett. 248:35-38.

15. Dayer-Metroz, M. D., C. B. Wollheim, P. Seckinger, and J. M. Dayer. 1989. A natural interleukin 1 inhibitor counteracts the inhibitory effect of IL 1 on insulin production in cultured rat pancreatic islets. J. Autoimmunity. 2:163-171.

16. Hughes, J. H., R. A. Easom, B. A. Wolf, J. Turk, and M. L. McDaniel. 1989. Interleukin 1-induced prostaglandin $E_{2}$ accumulation by isolated pancreatic islets. Diabetes. 38:1251-1257.

17. Zawalich, W. S., B. Dierolf, and K. C. Zawalich. 1989. Interleukin 1 induces time-dependent potentiation in isolated rat islets: possible involvement of phosphoinositide hydrolysis. Endocrinology. 124:720-726.

18. McDaniel, M. L., J. R. Colca, N. Kotagal, and P. E. Lacy. 1983. A subcellular fractionation approach for studying insulin release mechanisms and calcium metabolism in islets of Langerhans. Methods Enzymol. 98:182-200.

19. Pipeleers, D. G. 1984. Islet Cell Purification. In Methods in Diabetes Research. J. Larner, editor. 185-211. John Wiley \& Sons, New York.

20. Wang, J. L., and M. L. McDaniel. 1990. Secretagogue-induced oscillations of cytoplasmic $\mathrm{Ca}^{2+}$ in single $\beta$ and $\alpha$-cells obtained from pancreatic islets by fluorescence-activated cell sorting. Biochem. Biophys. Res. Commun. 166:813-818.

21. Orland, M. J., R. Chyn, and M. A. Permutt. 1985. Modulation of proinsulin messenger RNA after partial pancreatectomy in rats. $J$. Clin. Invest. 75:2047-2055.

22. Koranyi, L., M. A. Permutt, J. M. Chirgwin, and S. J. Giddings. 1989. Proinsulin I and II gene expression in inbred mouse strains. Mol. Endocrinol. 3:1895-1902.

23. Garrels, J. I. 1983. Quantitative two-dimensional gel electrophoresis of proteins. Methods Enzymol. 100:411-424.

24. Anderson, N. L. and Anderson, N. G. 1978. Analytical techniques for cell fractions: XXII. Two-dimensional analysis of serum and tissue proteins: multiple gradient-slab gel electrophoresis. Anal. Biochem. 85:341-354.

25. Hammonds, P., M. Beggs, G. Beresford, J. Espinal, J. Clarke, and R. J. Mertz. 1990. Insulin-secreting $\beta$-cells possess specific receptors for interleukin-1 B. FEBS (Fed. Eur. Biochem. Soc.) Lett. 261:97100.

26. Spinas, G. A., B. S. Hansen, S. Linde, W. Kastern, J. Molvig, T. Mandrup-Poulsen, C. A. Dinarello, J. H. Nielsen, and J. Nerup. 1987. Interleukin 1 dose-dependently affects the biosynthesis of (pro)insulin in isolated rat islets of Langerhans. Diabetologia. 30:474-480.

27. Helqvist, S., B. S. Hansen, J. Johannesen, H. U. Andersen, J. H. Nielsen, and J. Nerup. 1989. Interleukin 1 induces new protein formation in isolated rat islets of Langerhans. Acta Endocrinologica. 121:136-140. 